\title{
Melodram ve Tragedyanın Ahlaki Evreninin Çağan Irmak Filmlerindeki Dönüşümü
}

\author{
Duygu Turgay*
}

\begin{abstract}
Özet
Gerek melodram gerekse tragedya olsun her iki tür de ahlak dersi vererek ahlaki olanı vurgulamayı amaçlamaktadır. Melodram, ahlaksal ölçüler içinde sıralanmış olaylar dizisinden oluşan bir türdür. Aristoteles'in tanım ile tragedya da ahlaksal bakımdan ağırbaşl, başı ve sonu olan, belli bir uzunluğu bulunan bir eylemin taklididir. Çalışmada melodram ve tragedyanın ahlaki değer vurgusuna dayanan anlatısının Çağan Irmak filmlerine nasıl yansıdığı ve bu filmlerde bu yansımanın nasıl bir dönüşüm geçirdiği sorularına cevap bulmak amaçlanmıştır. Bu amaç doğrultusunda melodramın ve tragedyanın "ahlaki" tanımı ve bu tanımın her iki türün anlatı yapısına yansıması üzerinde durulmuştur. Ayrıca çalışmada Çă̆an Irmak'ın örneklem alınan filmleri incelenerek Çağan Irmak'ın "ahlak" kavramını nasıl ele aldığ̆ üzerinde de durulmaktadır. Çalışmada Çağan Irmak'ın Issız Adam (2008), Dedemin İnsanları (2011), ve Unutursam Fısılda (2014) olmak üzere üç filmi örneklem olarak alınmıştır. Çalışmada örneklem olarak alınan bu filmlerde melodram ve tragedya kavramlarn çerçevesinde sinematik imajlar incelenmiştir. Çağan Irmak, filmlerinde hem melodram hem de tragedyanın unsurlarından ve anlatı yapısından yararlanmaktadır. Ayrıca Çağan Irmak'ın filmlerinde, ahlaki değer vurgusu yaptı̆̆ı da söylenebilir. Fakat bu ahlaki değer vurgusu ne melodramda olduğu gibi keskin çizgilerle birbirinden ayrılmış zıtlıklar üzerinden yapılmakta ne de tragedyada olduğu gibi ahlaki yönden üstün karakterler ile gerçekleştirilmektedir. Çă̆an Irmak filmlerinde, toplumsal ahlaki normlardan ve de karakterlerin eylemlerinden çok, evrensel ahlaki normlara ve karakterlerin duygu durumlarına ağırlık verilerek bu filmler, ahlaki yönden melodram ve tragedya türlerinden farklılaşmıştır.
\end{abstract}

Anahtar Kelimeler: Melodram, Tragedya, Ahlak, Çă̆an Irmak Filmleri

ORCID ID : 0000-0002-3116-3772

E-mail : duyguturgay@gmail.com

DOI: $10.31122 /$ sinefilozofi.511812

Geliş Tarihi - Recieved: 11.01.2019

Kabul Tarihi - Accepted: 30.03.2019 


\title{
Transformation of Moral World of Melodrama and Tragedy on Çağan Irmak Films
}

\author{
Duygu Turgay*
}

\begin{abstract}
Both melodrama and tragedy, aim to emphasize ethicalness by moralise. Melodrama is a genre consisting of a series of events sorted in moral measures. According to the definition of Aristoteles, tragedy is imitation of an act which is morally earnest, has a beginning and a end, has a certain duration. In this study; it is aim to answer two questions: First, melodrama and tragedy' s narrative of grounding emphasis on moral value how to reflect to Çağan Irmak films and secondly in these films how to transform this reflection. In accordance with this purpose; it is emphasized the moral definition of melodrama and tragedy and the reflection of this definition to both genre's narrative structer. This study also investigated the sampling films of Çağan Irmak and how he handles the notion of morality. This study sampled three films of Çă̆an Irmak; Issız Adam (Deserted Man, 2008), Dedemin Insanları (Grandpa's People, 2011) and Unutursam Fisilda (Whisper it when I forget, 2014). It is investigated that, the cinematic images of that sample films, as part of melodrama and tragedy concepts. Çă̆an Irmak cites both melodrama and tragedy elements and narrative structures. That's also sayable that, Çağan Irmak emphasises moral value in his films. But he doesn't make this emphasis with obvious contrasts as melodrama; nor with topflight characters on moral ground as tragedy. Instead of social moral norms and acts of characters, he focuses on universal moral norms and moods of characters and becomes distinct from melodrama and tragedy on moral grounds.
\end{abstract}

Key Words: Melodrama, Tragedy, Morals, Çă̆an Irmak Films.

ORCID ID : 0000-0002-3116-3772

E-mail : duyguturgay@gmail.com

DOI: 10.31122/ sinefilozofi.511812

Recieved - Geliş Tarihi: 11.01.2019

Accepted - Kabul Tarihi: 30.03.2019 


\section{Giriș}

Ahlak temel olarak bir insanın neyi yapıp neyi yapmaması gerektiğini söyleyen kurallar bütünüdür. Ahlak konusunda Antik Yunan'dan günümüze tarihsel olarak değişen görüşler mevcuttur. Gerek melodram gerekse tragedya kendi dönemlerinin ahlak görüşünden etkilenmişlerdir ve her iki tür de ahlak dersi verme işlevini üstlenmektedirler. Dolayısıyla bu türler etkin oldukları ve ortaya çıktıkları dönemin ve de coğrafyanın ahlaki düzenini oluşturmak ve de bu düzeni pekiştirmek açısından önemli işleve sahip türlerdir.

Melodram, Fransız devriminden sonra ortaya çıkan bir türdür. Dolayısıyla melodramın ahlak anlayışında da bu dönemin yansımaları görülür. Bu dönemde toplumsal düşüncelerin değişmesinin etkisiyle yeni bir ahlak görüşü oluşturulmaya çalışılmış ve melodram da bu görüşün topluma yayılması ve de toplum algısında pekiştirilmesi görevini üstlenmiştir. Tragedya ise kökeni Antik Yunan'a dayanan bir türdür ve bu tür de yine Antik Yunan'da hakim olan ahlak anlayışının yansımasını sunar bizlere. Her iki tür de ahlak dersi verme amacı güden türlerdir. Dolayısıyla her iki türde de anlatı yapısı ve karakterler bu amaç doğrultusunda şekillenmiştir.

Çağan Irmak, filmlerinde hem melodram hem de tragedyanın anlatı unsurlarından yararlanmaktadır. Ayrıca Irmak, filmlerinde melodramın ahlaki olanı vurgulama ve de tragedyanın acı ve korku yoluyla tutkulardan arındırma işlevlerinden de yararlanmaktadır. Fakat Irmak filmlerindeki ahlaki görüş, melodram ve de tragedyadaki ahlaki görüşten farklılaşmaktadır. Bu çalışmada da Çağan Irmak filmlerinin melodram ve tragedyadan farklılaşan ahlak görüşünün ve bu ahlak görüşünün nasıl bir dönüşüm geçirdiğinin ortaya çıkarılması amaçlanmaktadır. Bu amaç doğrultusunda melodram ve tragedyanın ahlak anlayışına bakılacak ve bu türlerde ele alınan ahlaki görüş ile Çağan Irmak filmlerinde yansıtılan ahlak görüşü karşılaştırılacaktır. Melodram her ne kadar Fransız Devrimi ile şekillenen bir tür olsa da diğer ülke sinemalarına da uyarlanmış ve genel özelliklerini bu ülke sinemalarında da korumuştur. Çağan Irmak' ın Türk sinema yönetmeni olması ve de Yeşilçam'ın melodramın en popüler dönemini oluşturması nedeniyle çalışma melodramın ahlaki evreni açısından Yeşilçam melodramlarıyla sınırlandırılmıştır. Tragedya kavramında ise, tragedyanın kökeninin Antik Çağa dayanması nedeniyle, Aristoteles'in Poetika kitabı üzerinden yola çıkılarak tragedyanın tanımı ve ahlak anlayışı ele alınmaktadır.

Çalışmada Çağan Irmak'ın Issız Adam (2008), Dedemin İnsanları (2011), ve Unutursam Fısılda (2014) olmak üzere üç filmi örneklem olarak alınmıştır. Bu filmler Çağan Irmak'ın ahlak anlayışını yansıtan ve onun ahlaki görüşünü anlamamızı sağlayan filmlerdir. Çalışmada örneklem alınan filmler, bu filmlerdeki sinematografik imajlara bakılarak incelenecektir. İmaj gerçeğin zihnimizdeki yansımasıdır. Bu konuda değişik felsefecilerin görüşleri bulunmaktadır. Çalışmada Gilles Deleuze'ün hareket-imaj kavramı ve David Hume'un imaj ile ilgili görüşleri üzerinden filmler incelenecektir.

\section{Ahlak}

\section{Ahlak Kavramı}

Ahlak, köken olarak Arapça bir kelimedir. Bu kelime “bir insanın yaradılışı gereği gerçekleştirdiği davranışı dile getiren Arapça Hulk sözcügüüün çoğuludur. Bu kavram töre, gelenek, görenek, alışkanlık, yerleşik hale gelmiş duygululuk durumu ve karakter anlamlarını çoğul olarak kapsamaktadır" (Gündüz, 2010:2). Genel olarak "ahlak, insan ilişkilerinde 
iyi ya da doğru veyahut kötü ya da yanlış olarak adlandırdığımız değer yargılarını ifade eder"(Aktan, 2009:39). “Dar anlamda ahlak ise kişi vicdanının belirli hareketleri doğru ve iyi olarak vasıflandırırken kullandığı kuralların bütünüdür" (Barut, 2001:142). Nilgün Çelebi'ye göre (2003:6) ahlak; halk edilmişlerin halk edilmiş olmalarından dolayı birbirleriyle olan ilişkilerinde uymaları gereken kurallar manzumesidir. Ahlaki tavır ise, ötekinin de dikkate alındığının izini, işaretini taşıyan tavırdır. Dolayısıyla bu durum insanın davranışlarında neyin değerli olup neyin değerli olmadığı ve insanın hangi boyut çerçevesinde davranışlarını şekillendirmesi gerektiği sorularını da akla getirmektedir.

Ahlakla ilgili tanımlardan yola çıkarak Wren (Aktaran Gündüz, 2010:14-15) ahlakın kavramlaştırılması ile ilgili bir sınıflama yapmış ve bu kavramlaştırmaları altı başlık altında toplamıştır. Bunlardan ilki Erekbilimsel ahlak kavramsallaştırmasıdır. Bu kavramsallaştırmalar ahlakın amacını insanın mutluluğu, güzellik ve Tanrı gibi objektif, geniş kapsamlı değerler bulmak olarak görmüştür. Örneğin, Antik Yunan'da ahlak, bu kavramsallaştırma çerçevesinde mutluluk ile bağdaştırılmıştır. İkincisi Yargısal Ahlak kavramlaştırmasıdır. Bu kavramlaştırmada ahlak; yasalar, haklar ve zorunluluklarla ödevler arasındaki evrensellik göz önünde bulundurularak iki taraflı bağlantılar şeklinde açıklanmaya çalışılmıştır. Ahlakın kavram olarak üçüncü sınıflandırması kendini gerçekleştirme kavramsallaştırmasıdır. Buna göre ahlak benlik ve benlik özellikleri açısından değerlendirilir. Dördüncü kavramsallaştırma süreççi ahlak kavramlaştırmasıdır. Bu ahlak tanımında ahlaki eylemlerde akılcılık, yani iyice düşünme ve buna göre seçim yapma süreçleri vurgulanır. Wren'in yaptığ kavramı sınıflandırması sezgisel ahlak kavramlaştırmasıdır. Bu kavramlaştırmada ise kişinin sezgilerine göre ahlaki değerlerin ve ilkelerin algılanabileceği düşüncesi yer alır. Altıncı sınıflandırma romantik ahlak kavramlaştırmasıdır. Bu ahlak kavramlaştırmasına göre ahlaki karar, toplumsal kurumlardan ayrışarak, kişinin özgür iradesi ile var olabilir. Romantik ahlak kavramlaştırması toplumsal kurumların çoğuna karşı çıkar ve ahlakı özgürleşerek, eğitimli bir saflık durumuna gelme olarak görür. Bu kavramlaştırmalardan yola çıkılarak söylenebilir ki ahlak her ne kadar toplumsal yaşama yönelik kurallar olsa da tüm bu ahlakla ilgili görüş ve kavramlaştırmaların ortak yanı ahlakta "ruhsal ve sosyal unsurların bulunduğudur. İster akla ister duyguya dayansın her türlü ahlak anlayışında esas olan ahlakın, ferdin ruhsal yaşayışından doğmuş olduğudur" (Topçu, 2014:18).

\section{Ahlakla İlgili Görüşler}

Ahlakla ilgili olarak tarihsel ve de toplumsal bağlamda birbirinden farklılaşan görüşler mevcuttur. Örneğin Antik Yunan'da ahlak, mutluluk ile açıklanırken Ortaçağ Avrupası'nda ahlak teolojik bir boyut kazanarak kutsal metinlerle temellendirilmeye çalışılmıştır. 17. Yüzyıldan sonra ise Antik Yunan ahlak anlayışından ayrılan değişik ahlaki görüşler ortaya çıkmıştır. Bu dönem modern felsefenin de doğuşuyla ahlak anlayışında akılcılık görüşü önem kazanmıştır. On dokuzuncu yüzyıldan sonra ise ahlak, varoluşçuluk anlayışı ile açıklanmaya çalışılmıştır. Varoluşçulukta "bireyin uyması gereken hiçbir doğaüstü ya da doğaötesi davranış kodu yoktur. Yaşam kurallarımız, kendimiz için kararlaştırdığımız kurallardır." (Billington, 1997:237).

Antik Yunan'da ahlak anlayışı genellikle mutluluk ve de erdem üzerine temellendirilmiştir. Bu görüşe göre sonucunda insana mutluluk veren eylemler ahlakidir. Bu görüş sadece Antik Yunan'da değil, diğer dönemlerde de varlığını sürdürmüştür. Mutluluk ahlakının öncü savunucuları Platon ve Aristoteles'tir. Sokrates'in öğrencisi olan Platon 
Sokrates' in görüşlerinden etkilenmiştir. Dolayısıyla ilk başlarda iki düşünürün birbirine benzer görüşleri bulunur. Sokrates'e göre (Platon, 1998:22), insanın hayatı dünyanın hayatından daha önemlidir; asıl bilgi dünyayı değil, insanı bilmektir. İnsan kendi hayatını yönetmelidir; iyi ile kötüyü, doğru ile eğriyi ayırt etmesini öğrenip hem kendini hem başkalarını adam etmelidir. Dolayısıyla mutluluk öğrenilebilen bir olgudur ve bilgi ile de yakından ilişkilidir. Fakat bu bilgi insanı bilmeye dayalıdır ve bu bilgi insanın iyi ile kötüyü ayırt edebilmesini sağlar. Platon da kötülüğün bilgisizlik sonucu olduğunu savunur. O da Sokrates gibi, iyiliği bilmekle iyi olunacağını ve iyi eylemlerde bulunulacağını savunmaktadır. Fakat son zamanlarında Sokrates'ten farklılaşan görüşlerini ileri sürmüştür ve kötülüğün sadece bilgisizlikten değil, belli hastalıklardan da kaynaklanabileceğini savunmuştur. Platon'un ahlak görüşünde erdem ağırlık noktası olarak görülür.

Aristoteles de ahlakı mutluluk ile açıklamaktadır. Aristoteles'e göre (2014:29) eylemlerimizin amacı mutluluktur. Fakat ona göre ölçülülük de esastır. Bu ölçülülük ise akla ve aklın ölçülerine dayandırılmaktadır. Sokrates ve Platon'dan farklı olarak Aristoteles ahlaki davranışta bilginin değil, eylemin etkili olduğunu savunur. Bu nedenle erdemli olmak demek, erdemli hareket etmek demektir. Tüm bu düşüncelerin temelinde mutluluk kavramı yer alır ve insanı mutluluğa götüren ise erdem olarak kabul edilir. Antik Yunan'da ahlakla ilgili düşüncelerden bazıları da ahlakı haz ile ele almaktadırlar. Bu düşüncenin öncü savunucusu Aristippos'tur. Ona göre haz veren şey ahlakidir. İnsan eylemlerinin amacı da acı veren duygulardan uzaklaşarak haz veren duygulara yaklaşmaktır. Epiküros da hazza yönelik bir ahlak anlayışını savunur.

Ortaçă̆’a gelindiğinde ahlak görüşlerinde değişiklikler yaşandığı görülür. Antik Yunan'da mutluluk üzerine temellenen ahlak görüşü Ortaçağ'da dini temeller üzerine kurulmuştur. "Bu dönemde davranış Tanrı'nın insana nasıl yaşaması gerektiğini bildiren emirlerine uygun düşmekliğine veya düşmemekliliğine göre değerlendirilir. Tanrı, insan için yüce ve yüksek bir ideal getirdiğinden, Ortaçağ insanı eksikliğini, başarısızlığını ve günahkârlığını her daim duyumsamak durumunda olan biridir" (Cevizci, 2001:19). Ortaçağ' da dini metinlere dayalı otoriter bir ahlak anlayışı ile karşılaşılmaktadır. Ortaçağ'ın teolojik yaklaşımının yanında Antik Yunan ahlak görüşü de devam etmiştir.

On yedinci yy'dan sonra, Batı' da modern felsefeye geçisin de etkisiyle, Antik Yunanın mutluluk ve erdem üzerine kurulu ve Ortaçağ'ın teolojik ahlak görüşünden farklı görüşler ortaya çıkmıştır. Geçmiş çağlardan farklı olarak bu dönemdeki düşünceler insan temel alınarak oluşturulmuştur ve hakim görüş akıl ve rasyonellik üzerinedir. Bu dönem Thomas Hobbes, Rene Descartes, Baruch Spinoza ve 18. Yüzyılda İmmanuel Kant gibi düşünürlerin ahlakla ilgili görüşleri bulunmaktadır. Descartes (1942:77) hakikati aramanın en büyük erdem olduğundan bahseder. Bununla birlikte onun ahlak görüşünde düşünce de önem taşımaktadır. Çünkü iyi ve doğruya akıl yoluyla ulaşılabilir. Hobbes da (2007:97) ahlak görüşünü insanın varlığını korumasıyla ilişkilendirir. Fakat bir kişi, başkaları da aynı şekilde düşündüklerinde, barışı ve kendini korumayı istiyorsa her şey üzerindeki bu hakkını bırakmalı ve başkalarına karşı ancak kendisine karşı onlara tanıyacağı kadar özgürlükle yetinmelidir. Dolayısıyla kişinin varoluşundan daha önemli olan toplumun varoluşudur. Doğa-tanrıcı bir düşünür olan Spinoza' nın da ahlak konusunda düşünceleri bulunmaktadır. Spinoza düşüncelerini doğa ile bağdaştırmaktadır. Ona göre insan doğanın bir parçasıdır ve de doğada nedensellik vardır. Dolayısıyla insan da nedensellik ilişkisi içerisindedir ve ahlaki olan bakımından da nedensellik 
önem taşır. Spinoza' ya göre ahlaki davranış, "insan doğasının herkesin boyun eğmek zorunda olduğu yasaları olarak ortaya çıkar; bu yasalara, duygularının köleleştirdiği insanın körce ve gerçek nedenleri bilmeden itaat ettiği yerde, şeylerin zorunlu düzenine ilişkin sağlam kavrayışa ulaşmaya çalışan özgür insan tarafından hakiki anlamları kavranarak uyulur" (Cevizci, 2001a:146-147 ). 18. yüzyıl düşünürü olan Kant da ahlakı akılla ilişkilendirmektedir. Ona göre ahlaksal kavramlarının yer ve kaynağı priori olarak akılda bulunur. Kant, ödev ahlakının savunucusudur ve evrensel bir ahlak yasası olup olmadığı sorusunu tartışmıştır. Kant ahlaki olanı ödev ve genel ahlak yasalarıyla açıklamaktadır. Ona göre (2002:27) ödevin ve genel olarak ahlak yasasının saf, deneysel uyarıcıların yabancı hiçbir şey katmadı̆̆ı tasarımının, insanın kalbi üzerinde yalnızca akıl yoluyla deneysel alanın sunabileceği diğer bütün güdülerden daha güçlü bir etkisi vardır; bu tasarım, değerliliğinin bilinciyle bu güdüleri küçümser ve zamanla egemenliği altına alabilir. Dolayısıyla kişinin ahlaki eyleminde etkilidir.

On dokuzuncu yüzyıl itibariyle varoluşçu düşünce etkisini göstermeye başlar. İlk varoluşçu düşünür Soren Kierkegaard'dır. Kierkegaard'a göre tanrı inancı ile akıl birbirinden ayrılmaktadır. Friedrich Nietzsche' nin de ahlakla ilgili görüşleri bulunmaktadır. Nietzsche'ye göre (2001:21) her durumda bir şeyler aşılmalıdır. Ahlak da kendi kendini aşmalıdır. Jean Paul Sartre da ahlaki olanı özgürlük ile bağdaştırmıştır. Sartre, insanın eylemlerinde özgür olması gerektiğini savunmaktadır. Dolayısıyla ahlaki eylemin temelinde de özgür irade olmalıdır.

\section{Ahlakın Temel Kavramları}

Ahlak ile ilgili görüşleri olan düşünürler, ahlaki davranışın temelinde ne olduğu konusuyla ilgilenmiş ve bazı temel kavramları incelemişlerdir. Ahlak felsefesinin incelediği bu temel kavramlar; iyi, kötü, sorumluluk, özgürlük, vicdan, erdem, ahlaki karar, ahlaki erdem, mutluluk ve ödev kavramlarıdır. İyi ve kötü birbirine zıt kavramlardır. Dolayısıyla iyi tanımının karşıtı kötüdür. Sorumluluk, kişinin yaptığı eylemin sonuçlarını üstlenmesidir. Özgürlük, kişinin özgür iradesi ile karar vermesi ve eylemlerini gerçekleştirebilmesidir. Vicdan, kişinin iç sesidir. Erdem, iyiye yönelme durumudur. Ahlaki karar ve de ahlaki eylem kişinin özgür iradesi ile bağlı olduğu ahlak yasalarına uygun karar vermesi ve de bu kararı eyleme geçirmesidir. Mutluluk, insanın gerçekleştirdiği eylemin sonucunda ruhsal huzurunun olmasıdır. Ödev ise kişinin ahlak yasasına uygun şekilde davranmasıdır.

\section{İyi-Kötü}

Ahlak deyince ilk akla gelen kavramlar iyi ve kötü kavramlarıdır. "İyi, insanın insan olma değerine ve yaşadığı topluma yararlı ve değerli olandır" (Çüçen, 1999:287). Bu tanıma göre iyi, kişinin yaşadığı toplum değerlerine bağlıdır. Bir başka tanıma göre "iyi, ahlak açısından ahlaki eylemin ulaşmak istediği nihai hedeftir. Her ahlaki eylem sonuçta iyiye ulaşmak ister. İyi, kendi başına var olan bir değerdir" (Gökalp, 2010:22).

Epiküroscular iyiyi haz veren şey olarak tanımlarken stoacı düşünce iyiyi erdemli yaşam olarak tanımlamaktadır. Aristoteles'e göre (2014:26) bir şey kendisi olduğu için aranıyorsa ya da kendinden dolayı seviliyorsa iyidir. Bu durumda iki türlü iyi bulunmaktadır. Kimi şeyler kendilerinden dolayı, kimi şeyler ise çeşitli nedenlerden dolayı iyi sıfatını hak ederler. Soktates'e göre (Platon, 2013:66) ise manevi nitelikler tek başlarına iyi ya da kötü anlamına gelmezler. Onlar bilgelik ya da aptallığın varlığına bağlı olarak yararlı ya da zararlı hale dönüşürler. Erdem de yararlı bir şey olarak bir tür bilgelik olmak zorundadır. Sokrates iyi olanı bilgi ile açıklamaktadır. Dolayısıyla bilgili olan insan iyidir. Platon da benzer bir 
görüşe sahiptir Platon’a göre ise “en yüksek iyi, bilgi ve hazzın ölçü, güzellik ve doğruluğa göre birleşmiş bir karışımıdır" (Akarsu, 1998:106). Bu düşünceye göre iyi olan bilgi, mutluluk ve güzellikle bağlantılıdır. Fakat bunun yanında ölçünün de olması gerekir. Platon'a göre (1999:79) kölelik de, özgürlük de ölçüyü aşarsa kötüdür; Tanrıya boyun eğmek de ölçülü bir davranıştır; insana boyun eğmek ise ölçüsüzlüktür. Aklı başında kimselerin yasası Tanrı, akılsız kimselerin yasası zevk ve sefadır. Platon'un bu görüşünden köleler gibi alt sınıfların da iyi olabileceği, fakat iyi olmanın altında ölçülülüğün yattığı düşüncesi anlaşılmaktadır. Aristoteles (2014:31-33) iyi olan şeyleri üç gruba ayırır. Bunlar, dışsal iyiler, ruha ait ve bedene ait iyilerdir. Ruhla ilgili iyiler gerçek iyilerdir. Eylemler ve ruhsal eylemler de bunlara dahildir. Bir şeyin güzel bulunması ruhta olur, bu da ruhta sevilen şeydir. Erdeme uygun eylemler de bu şekildedir. Bu eylemlerin hem kendileri hoştur hem de erdemi sevenler açısından bu eylemler hoş kabul edilir. Dışsal eylemler olmadan yaşamak zordur. Dostlar, zenginlik, siyasi güç gibi dışsal iyiler de kişinin yararınadır.

Kant'a göre (2002:5) ahlakça iyi olması gereken için, bir şeyin sadece ahlak yasasına uygun olması yetmez, aynı zamanda ahlak yasasının uğruna da yapılmıs olmalıdır; yoksa o uygunluk yalnızca rastlantısal ve belirsizdir. Ayrica Kant (2002:16) ahlaksal diye adlandırabileceğimiz eşsiz iyiyi, ancak akıl sahibi varlıklarda bulunan - ve istemeyi, umulan etki değil de, bu tasarım belirlediği ölçüde- yasa tasarımının kendisinden başka bir şeyin oluşturamayacağını söylemektedir.

Spinoza, iyiliği ve kötülüğü yine doğa bağlamında açılamıştır. Spinoza'ya göre (2011:200) iyilik deyince, kesinlikle bize faydalı olduğunu bildiğimiz şeyi; kötülük deyince, tersine, bir iyiliğe sahip olmamıza engel olduğunu kesinlikle bildiğimiz şeyi anlarız. Bu açıdan iyi ve kötü doğamızla uyuşan ya da uyuşmayan bir anlama sahiptir. Dolayısıyla Spinoza'ya göre kendi doğası ile uyuşan şeylerle birleşmek için, kendi ilişkilerini, kendi ilişkileriyle uyuşan ilişkilerle birleştirerek gücünü arttırmak için karşılaştığı şeyleri elinden geldiğince düzenlemeye çalışan birey, iyi olarak adlandırılır.

\section{Özgürlük}

Ahlak açısından özgürlük kişinin aldığı kararları ve de eylemleri özgür iradesi ile gerçekleştirmesi anlamına gelmektedir. “Özgür olmak varoluşun sonsuz zorluklarını tanımak ve ahlaki davranışın hazır reçetesinin olmadığını fark etmek demektir" (Billington, 1997:302). Dolayısıyla ahlaki bakımdan olgun olan kişi davranışını belli bir kişi ya da kişilerin ihtiyaçlarına göre belirlemekte özgürdür. Platon'a göre, "ruhun gerçekten değerli olan bölümü, hem iradeye, hem de içgüdülere hâkim olan akıldır. İçgüdüler kötüdür. İrade ise, ancak içgüdülere karş1 olduğu ve aklın buyruğuna uyduğu vakit iyidir"(Birand, 1958:60).

Spinoza'ya göre (2011:123) irade ve zihin tekil istekler ve fikirlerden başka bir şey değildirler. Halbuki tekil istek ve fikir tek ve aynı şeyden ibarettirler; o halde irade ve zihin tek ve aynı şeyden ibarettir. Kant'a göre de kişiler eylemlerinde özgür olmalıdır. Ona göre (2002:64-71) isteme, akıl sahibi olmaları bakımından, canlı varlıkların bir tür nedenselliğidir ve özgürlük bu nedenselliğin, onu belirleyen yabancı nedenlerden bağımsız olarak etkili olabilme özelliğidir. Doğa zorunluluğu ise, akıl sahibi olmayan bütün varlıkların nedenselliğinin, yabancı nedenlerin etkilemesiyle etkin olmaya belirlenmesi özelliğidir. Kant'a göre özgür bir isteme ile ahlak yasaları altında olan bir isteme aynı şeydir. Bunun yanında duyular dünyasının belirleyici nedenlerinden bağımsız olma (aklın, kendisine hep yüklemesi gereken bu bağımsızlık) özgürlüktür. Jean Jacques Rousseau' ya göre de (1987:15-30) özgürlük insan 
doğasının bir sonucudur. İnsanın ilk uyacağı yasa ise, varlığını koruması ve kendisine özen göstermesidir. Bununla birlikte salt isteklerin itişine uymak özgürlük değil köleliktir, kendimiz için koyduğumuz yasalara boyun eğmekse özgürlüktür. Rousseau, özgürlük için eşitliğin olması gerektiğini de savunmaktadır. Tüm bu görüşlerden anlaşılmaktadır ki ahlaki eylemin ve de ahlaki kararın olabilmesi için kişinin özgür iradesinin olması gerekir ki bu özgür irade de kişinin seçim yapabilmesi anlamına gelmektedir. Kişinin seçme özgürlüğü ise ancak akıl ile gerçekleşebilir.

\section{Vicdan}

Vicdan bir insanın eylemlerinde iyi ve kötüyü ayırt ederek bir yargıda bulunması durumudur. Bu açıdan vicdan kişinin eylemde bulunurken başvurduğu iç ses, iç mahkemedir. Erich Fromm (2005:162-179) vicdanı iki şekilde ele almaktadır. Bunlar otoriter vicdan ve insancıl vicdandır. Otoriter vicdan kişi için içselleşmiş bir dış otoritenin sesidir. Bu diş ses, devlet, aile bireyleri ve toplumdaki kültürel otoriteler olabilir. Bu vicdanda cezalandırma ve mükafatlandırılma durumu kişinin eylem ve kararları üzerinde etkilidir. Bir kişinin çekindiği dışsal otorite o kişinin içsel otoritesini yani vicdanını besleyen kaynağıdır. Otoriter vicdan için iyi vicdan, otoriteyi memnun etme, suçlu vicdan ise onları memnun etmeme bilinçliliğinden kaynaklanmaktadır. İnsancıl vicdan ise kişinin kendi sesidir. Bu vicdan dış yaptırımlardan ve de ödüllendirmelerden bağımsızdır. Vicdan sadece aklımızın değil, tüm kişiliğimizin tepkisi olduğundan duygusal bir özelliğe de sahiptir. Tüm kişiliğimizin işlemesine ve de açlımına neden olan eylemler, düşünce ve duygular insancıl iyi vicdanın özelliklerindendir. Bu durumun tersi olarak tüm kişiliğimizi zedeleyen eylem, düşünce ve duygular ise suçlu vicdana özgü rahatsızlık ve huzursuzluk hislerini tetikler. Yani vicdan iç sesimizin bize verdiği tepkidir. Kısaca insancıl vicdan insanın öz çıkarının ve bütünlügüünün ifadesidir.

\section{Erdem}

Erdem kişinin sürekli iyi ve de değerli olana yönelmesidir. “Erdem, kişinin ahlaki gelişmişliği ve olgunluğunun bir yansıması olarak kabul edilir" (Gökalp, 2010:22). Erdemli insan, sadece kendisi için iyi olanı değil, başkaları için de iyi olanı düşünerek hareket eder. Sokrates'e göre (Platon, 2013:43) erdem iyi şeyleri elde etme isteğidir. Fakat iyiye ulaşmada adalet ve ölçülülüğün de olması gerektiğini savunur. Spinoza'ya göre (2011:201-240) insana atfedilmesi (nispet edilmesi) bakımından erdem, sırf kendi tabiatının kanunlarıyla tanınabilen bazı şeyleri yapmak gücüne sahip olmak bakımından, insanın özü ya da tabiatıdır. Erdemin birinci ilkesi ise kendi varlığını korumaktır. Ve bu Aklın düsturuna göre olur, öyle ise her kim kendi kendisini bilmezse, bütün erdemlerin ilkesini ve bunun sonucu olarak bütün erdemleri de bilmez.

Platon'a göre (2012:24) ak1llılık, zekilik, bilgelik, ölçülülük ve cesaret, adaletin ön koşuludurlar ve bütün bunlar, biricik tek erdemin basamaklarından başka bir şey değillerdir; insanlara güç, enerji ve yetenek veren bu erdem, insan olmak, tanrıyı andıran ruhun taşıyıcısı olmaktır. Aristo ise erdemi ölçülülük ile açılamaktadır. Antik Yunan'da genel olarak mutluluk, erdem ile açıklanmaktadır. Erdem ise akla, iyi ve güzel olana dayandırılmıştır. Kısaca kişiyi mutluluğa götüren erdemdir ve kişinin ahlaki davranışı gerçekleştirebilmesi için erdemli olması gerekir.

\section{Melodramın Ahlaki Evreni}

Melodram, ahlak dersi veren bir tür olarak karşımıza çıkmaktadır. Dolayısıyla 
melodramın bir işlevi de ahlaki değer vurgusu yapma işlevidir. Melodramın tarihsel gelişimine bakıldığında kökeninin Ortaçağ ahlaki oyunlarına ve masallar, türküler gibi sözlü anlatılara dayandığı görülmektedir. "Ortaçağ ahlaki oyunları, toplumun Hristiyanlığa bağlı bir şekilde yaşaması için, bu dinsel öğretinin temellendiği değerleri işler, iyilik ve erdem niteliklerine vurgu yapar. Sözlü anlatı gelenekleri ise masallar, efsaneler, halk öyküleri gibi geniş alanı kapsar" (Akbulut, 2008:36). Melodramlarda da iyilik ve erdem niteliklerine vurgu yapilır ve bu nitelikler geleneksel ve muhafazakar bir ahlak anlayışı çerçevesindedir.

Melodramın bir kaynağını da tragedya oluşturmaktadır. Her ne kadar melodram tragedyaya karşı ortaya çıkmış bir tür olsa da tragedyadan tamamıyla bir kopuş da sergilemez. Örneğin tragedyanın anlatı yapısındaki pathos (acı veren) melodramlarda da bulunmaktadır. Melodram anlatılarını mağdur karakterler oluşturur, bu mağdur karakterin başına peş peşe ve aşırı bir şekilde trajik olaylar gelmektedir. Melodramın ilk kullanımında belirgin biçimde yer alan bu aşırılık hali Mehmet Fatih Uslu'ya (2011:84) göre melodramın nasıl yoğun bir ahlaki yükle dolu olduğunun göstergesidir. Bu ahlaki yük, oyunların tüketicileriyle kurulan ilişkinin de temel zeminini oluşturmuştur. Böylelikle seyircinin zihnindeki keskin çizgilerle ayrılmış iyi - kötü karşıtlığı pekiştirilmiş olmaktadır. Karakterin başına acı veren olayların gelmesi ile izleyici ve karakter arasında bir yakınlık kurulmaktadır.

Brooks'a (1995:20) göre melodram sadece ahlakçı bir tiyatro değildir; ahlaki evrenin varlığını kanıtlamak, ifade etmek, göstermek, bulmaya çalışmakla birlikte, kötü niyetlerle ve sapıklıkla da maskelenmiştir. Melodram sadece ahlaki değerleri yansıtmakla kalmaz; aynı zamanda Brooks'un dediği gibi iyilik ve ahlaki olanı, hayal gücü ile yansıtarak toplumdaki ahlak anlayışını da pekiştirir. Melodramlar kendince ahlaki olmayanı da göstererek ikisi arasında bir karşılaştırma sunar bizlere. Bu nedenle de melodram anlatılarında belirgin zıtlıklarla ahlaki ve gayri ahlaki birbirinden ayrılmıştır. Melodramın ahlak anlayışının temelinde ise iyi ve kötü kavramları yer almaktadır.

Melodram tür olarak Fransız Devrimi'nden sonra ortaya çıkan ve tragedyaya karşı duruş sergileyen bir türdür. Fransız Devrimi'nin ahlak açısından önemli bir sonucu insan haklarına yaptığ1 vurgudur. Bu dönem değişen düşünce yapısı ile yeni bir toplum ve ahlak düzeni oluşturulmaya ve oluşturulmaya çalışılan bu düzenin toplum tarafından benimsenmesine çalışılmış, melodram ise bu amacı gerçekleştirme işlevini üstlenmiştir. Melodram bu ahlak anlayışını zıtlıklar üzerinden vermeye çalışır. Yeşilçam melodram anlatıları da zıtlıklar üzerine kurulmuştur. Melodram, klasik anlatı yapısına sahip bir türdür. Klasik anlatının bir özelliği olan her şeyi açılama ve görünür kılma anlayışı melodramlar için de geçerlidir. Dolayısıyla melodramlar da neyin ahlaki neyin ahlaki olmadığını, özellikle karakterler üzerinden belirgin farklılıklar yaratarak ve de geride hiçbir soru işareti kalmayacak şekilde izleyiciye açıklar. İzleyici kimin ve neyin iyi, kimin ve neyin kötü olduğu kanısına kolaylıkla varır. Ayrıca bu şekilde izleyicinin iyi karaktere yakınlık duyması ve mükafatlandırılması isteği sağlanırken, kötü karaktere karşı cezalandırılma isteği oluşmasına da fırsat sağlanmış olur.

Melodram genellikle ahlaki olanı olaylar üzerinden değil, karakterler üzerinden sunar. Örneğin iyi kadın karakterlerin yanında birbiriyle tamamıla zıt olan kötü kadın karakterlere de rastlanır. İyi karakterler her yönleri ile iyidir, kötü karakterler ise her yönleriyle kötüdür. "Sadık eşin karşısında aldatan eş, namuslu kadının tam karşısında iffetsiz kadın, fedakar anne ki genelde öz annedir, karşısında fedakar olmayan üvey anne" (Özsoy, 2004: 287). Öyle ki “iyi olan karakterler, saflıklarıyla, dürüst, temiz, namuslu olmalarıyla daima aşkı hak ederler. 
Kötü olanların tek düşüncesi ise onların bir araya gelmelerini önlemektir. Bunun için yalan söylerler; iftira atarlar; hile yaparlar" (Akbulut, 2008: 107). Bu karakterler aralarındaki fark1 belirginleştirmek amacıyla fiziksel özellikleri açısından da birbirinden farklılaşır. İyi kadın karakterlerin saç rengi genellikle esmerdir. Kötü kadın karakterler ise sarışındırlar. Dolayısıyla melodram açısından zıtlıklar iyi ve kötü olanın algısı ve de ayırdı için önemlidir.

Melodramların ahlak açısından bir özelliği de kaderci bir anlayışa sahip olmalarıdır. $\mathrm{Bu}$ anlayış negatif konumlanmış özne kullanımı ve ilahi bir gücün iyi karakter üzerindeki etkisi ile görünür kılınmaktadır. "Asya sinemalarında melodramın önemli bir unsuru, "negatif olarak kurulmuş" özne konumudur. Seçim yapan, karar alan, harekete geçen, olaylara yön veren etkin özne konumunun aksine, "negatif olarak kurulmuş özne" edilgen, kendini silen, olaylar tarafından yönlendirilen bir konumu ifade eder" (Suner, 2006:187) Yeşilçam melodramlarında da karakterler negatif konumlanmış özne konumundadırlar. Bu melodramlarda başına gelen talihsiz olaylara karşı edilgen konumda olan karakter ilahi bir güç tarafından yönlendirilir. Melodram anlatıları mutlu son ile biter. Bu da melodramlardaki kaderci anlayışın bir yansımasını sunar. Her yönüyle iyi olan karakter sonunda ilahi bir şekilde mükafatlandırılırken kötü karakter cezalandırılır. İyi karakterler başlarına gelen bu talihsiz olaylar karşısında hem mağdur duruma düşerken hem de yaptıkları hataların cezasını da çekmektedirler. Buradan da anlaşılabileceği gibi melodramlardaki ahlak anlayışının teolojik, geleneksel ve de muhafazakar bir ahlak anlayışı olduğu söylenebilir.

Melodramlar, kendi dönemine ait toplumdaki baskın düzenin ve anlayışın bir yansımasını sunmaktadırlar. Dolayısıyla Yeşilçam melodramlarında ataerkil bir toplumun yansımaları görülmektedir. Ahlak açısından bakıldı̆̆ında da melodramlardaki ahlaki anlayış toplumsal alg1 ve baskın düşünce ile şekillenmektedir. Melodramlarda ideal bir kadın modeli sunulmaya çalışılmaktadır. Bu kadın modeli ise iyi kadın karakterler üzerinden sunularak erkeğin görmek istediği kadın modelidir. Dolayısıyla melodram kadınları, iyi bir eş, iyi bir anne ve de iyi bir vatandaştır. Karakter özelliği olarak da sadık, fedakar, sabırlı, namuslu ve erdemlidirler. Bu karakterler sevdikleri erkeklere karşı özverilidir ve sevdikleri erkeklerin istekleri doğrultusunda davranışlarını değiştirebilirler.

\section{Tragedyanın Ahlaki Evreni}

Aristoteles, Poetika isimli kitabında tragedyanın tanımını yapmakta ve de unsurlarını açıklamaktadır. Aristoteles tragedyayı şöyle tanımlar: "Tragedya ahlaksal bakımdan ağırbaşlı, başı ve sonu olan, belli bir uzunluğu bulunan bir eylemin taklididir; sanatça güzelleştirilmiş bir dili vardır; içine aldığı her bölüm için özel araçlar kullanır; eylemde bulunan kişilerce temsil edilir" (1987:22). Tragedyanın kökeni Antik Yunan'a dayanmaktadır. Nitekim bu dönem ahlak görüşünü de yansıtır. "Platon'a göre tragedya insanın kötü duygularına, ölüm korkusuna yöneliktir" (Nutku, 1990:36).Tragedyanın ahlaki açıdan önemli bir özelliği kişilerin başına gelen talihsiz olaylar yoluyla ahlak dersi vermesidir.

Aristoteles (1987:23) tragedyanın altı unsuru olduğunu belirtmektedir. Bunlar 1. Öykü, 2. Karakterler, 3. Dil, 4. Düşünceler, 5. Dekor ve 6. Müziktir. Bu unsurlardan dil ve müzik taklit araçlarını, dekor taklit tarzını, diğerleri ise taklit nesnelerini göstermektedir. Bu unsurlarda en önemlisi olay dizilerinin birbirine uygun biçimde bağlanmasıdır. Çünkü tragedya karakterlerin değil, onların eylemlerinin, mutluluk ve felaket içinde yaşadıkları hayatın bir taklidini oluşturmaktadır. 
Aristoteles'e göre tragedyada olay dizisi önemlidir. Çünkü "karakter, aksiyon ile biçimlenmektedir" (Nutku, 1990:44). Tragedyada karakter doğuştan iyi ya da kötü değildir. Karakterin ahlaki olarak iyiliğini belirleyen onun eylemleridir. Olay dizisi tamamlanmış ve de belli bir bütünlüğe sahip olmalıdır. Bu bütünlüğe Aristoteles hareket birliği demektedir. "Hareket (eylem) Birliği, olayların belli bir konu çevresinde toplanması ve birbirini olasılık ve zorunluluk kurallarına göre izlemesi demektir" (Şener, 2006:33). “Olasılık, yaşamda olmasa bile, bir tragedyada akla ve duyguya uygun düşen ölçüdür. Zorunluluk ise, birbirini izleyen olayların belli bir gelişim zinciri ile kurulu olmasıdır" (Nutku, 1990:42). Antik Yunan'daki ahlaki olanın akıl ile bulunabileceği düşüncesi tragedyanın anlatı yapısına da yansımaktadır. Neden sonuç ilişkisi bağlamında düşünüldüğünde bir olayın kendinden önce gelen olayla mantıksal bir bağının olması gerekir. Dolayısıyla bir olay kendinden önce olan bir olayın zorunlu bir nedenini oluşturmaktadır. Tragedyanın olay dizisi mantıksal bir düzlemde ilerlemekle birlikte beklenmedik olaylara da yer verilmektedir. Bu beklenmedik ve olağanüstü olaylar korku ve acıma duyguları ile oluşur.

Tragedya gerçeğe yakın bir türdür. Melodramda olduğu gibi karakterler trajik olaylarla karşılaşır fakat melodramın abartı yapısı tragedyada yer almaz. Bu gerçeklik karakterin gerçek hayatta yaşayan insanların olduğu gibi sunulması ile de kendisini gösterir. Aristoteles (1987:42-45), tragedya karakterlerinin dört özelliği olduğundan bahseder. Bunlar 1. Ahlaki olarak iyi olmaları 2. Niteliğine uygun olmaları: İçinde bulunduğu toplumdaki konumuna uygun hareket etmelidir. 3. Benzerliğin olması: Karakter koşullar çerçevesinde inandırıcı ve gerçeğe benzer biçimde hareket etmelidir. 4. Tutarlı olmaları: Karakter tutarlı davranışlar sergilemelidir. Karakterin tüm bu özellikleri ahlaki olanın karakterin kendi karakteristik özelliğinin bir sonucu değil eylemlerinin bir sonucu olarak şekillendiğini göstermektedir. Bu dönem Antik Yunan mutluluk, erdem ve de bilgiye dayanan ahlak anlayışının yansımaları tragedyanın anlatı yapısında görülmektedir. Ahlaki olarak üstün bir karakter ile izleyicinin karaktere yakınlık duyması sağlanmaktadır. Böylece ahlaki olarak üstün bir karakterin de bilgisizlik sonucu hata yapabileceği ve bu dönem ahlakiliğin bilgi ile bağdaştırıldığı görüşü anlaşılabilmektedir. Karakterler iyilerdir fakat hatasız değillerdir. Karakterin niteliğine uygun hareket etmesi ise Antik Yunan'da daha düşük görülen kadın ve kölelerin de ahlaki olarak iyi olabilecekleri düşüncesini göstermektedir. Dolayısıyla bu durumdan ahlaki olanın, kişinin statüsü ile alakalı olmadığı anlaşılabilmektedir. Tragedyada karakterler tutarlıdırlar, çünkü karakterler özlerinde iyidirler ve de kişisel özellikleri değişmez. Asıl değişen bu kişilerin bilgileridir. Bunu da deneyimleyerek öğrenirler ve başlarına gelen olaylardan bir ders çıarırlar. Ayrıca tragedyalar karakterin yenilgisi ya da ölümü ile sonuçlanır. Çünkü kişinin mücadele ettiği durum karakterin arzusundan çok daha değerlidir. Dolayısıyla tragedyadaki ahlak anlayışı kişi odaklı değil, toplum odaklı, erdeme dayalı bir ahlak anlayışıdır. Kişiyi mutluluğa götüren ise erdemdir.

Dil, müzik ve dekor da tragedyayı zenginleştiren taklit araçlarıdır. Tragedyanın bir unsuru düşüncedir. "Aristoteles', düşünce öğesi ile bugün "tez" ve "tema" dediğimiz öğeyi belirtmektedir. Oyunda ileri sürülen bir görüş, bir konu, bir öneri, ya da bir sav, oyunun düşünsel içeriğini oluşturur. Poetika'da düşünce, toplum ahlakına bağlıdır; doğru ve olası da olmalıdır" (Şener, 2006:39). Dolayısıyla düşünce önemli bir yer teşkil eder.

Tragedyanın ahlak anlayışını inceleyebilmek için olay dizisinde yer alan bazı kavramlardan da kısaca bahsetmek gerekir: Bu kavramlardan biri "hamartia" dır. Hamartia, 
"trajik kahramanın yaptığı bir hatayla bahtında bir dönüşüm olmasıyla ortaya çıkan trajik durumdur" (Nutku, 1990:48). Peripetie (baht dönüşümü) kavramı da hamartia ile benzerlik gösterir. Fakat "Peripetie, eylemlerin düşünülenin tam tersine dönmesidir. Bu da, olasılık ya da zorunluluk yasalarına uygun olarak oluşur" (Aristoteles, 1987:34). Peripetie, kader ile gerçekleşen baht dönüşümüdür. Dolayısıyla peripetiede karakterin hatası söz konusu değildir. Peripetie ile ilişkili olan Anagnorisis kavramı ise tanınma anlamındadır. Bu kavram bilgisizlikten bilgiye geçişi ifade etmektedir. Anagnorisis “Aristoteles'in Poetika'sında birinin ötekini çeşitli izlerden, eşyalardan ve yaptığı hareketlerden dolayı tanıması" (Nutku, 1990:237) olarak tanımlanmaktadır. Tragedya anlatılarında pathosa da yer verilmektedir. Bu kavram Aristoteles'e (1987:35) göre acı veren hareket olarak nitelendirilmektedir. Tragedya ile ilgili bir diğer kavram da katharsis (arınma) kavramıdır. Bu kavram tragedyanın işlevi olarak karşımıza çıkar. Tragedyada karakterin tutkularından arınması korku ve acıma duyguları ile sağlanmaktadır. Aristoteles'e (1987:37) göre katarsisin oluşmasını sağlayan acıma, layık olmadığı halde acıya uğramış bir kimse karşısında duyulur. Korku da, acıyı çekenle izleyici arasında bir benzerlik bulunması ile sağlanır. Bu nedenle tragedya karakterleri gerçeğe uygun karakterler olmalıdırlar. Ayrıca karakter ahlaki yönden üstün olmalıdır ki mutluluktan felakete düşmesi ile izleyicide korku ve de acıma duyguları uyandırılabilsin.

Kısaca tragedyanın tüm bu özellikleri ve de tanımı göz önünde bulundurulduğunda tragedyanın anlatı yapısının Aristoteles'in ve de yaşadığ1 dönemin ahlaki görüşünün bir yansımasını sunduğu söylenebilir. Dolayısıyla tragedyanın ahlaki görüşünün bilgi, erdem ve de Antik Yunan'daki mutluluk temeline oturtulduğunu söylemek doğru olacaktır.

\section{Çăgan Irmak Filmlerinde Ahlaki Görüş}

Çalışmada film analizlerinde ahlakla ilgili sinematografik imajlara bakılacaktır. İmaj gerçeğin zihnimizdeki yansımasıdır. Bu yansıma görüntü ile de bağlantılıdır. Henri Bergson Madde ve Bellek kitabında imgeyi kavranan madde olarak tanımlamaktadır. Jean Paul Sartre (2009:15) ise imajın bedensel bir şey olduğunu savunur. Ona göre imaj dış bedenlerin sinirler ve duyular aracılığıyla kendi bedenimiz üstündeki eylemin ürünüdür. İmajlar algılarımızı etkiler. David Huméa göre (2009:358) insanlar güçlü bir biçimde imgelemleri tarafından yönetilir ve duyguların herhangi bir nesnenin gerçek ve asıl değerinden çok kendilerine göründüğü 1şığı dikkate alarak belirlerler. Onlara güçlü ve diri bir tasarım ile çarpan şeyler genellikle daha bulanık bir ışıkta görünenlere baskın çıkar.

Deleuze, sinemayı hareket imaj ve zaman imaj kavramlarıyla incelemektedir. Gilles Deleuze' e göre (2014:13) sinema bize, dolaysız olarak bir hareket-imaj verir. "Hareket-imaj1, mantıksal neden-sonuç ilişkileriyle örülmüş, zaman-mekan bütünlüğüne sahip, kendi içinde tutarlı bir kurmaca dünya sunar. İmgeler kendi içlerinde tanımlanabilir, ayırt edilebilir ve diğer imgelerle iç tutarlık ve süreklilik içeren bir zincir oluşturacak biçimde ilişkilendirilebilir" (Suner, 2006:120). Deleuze'e göre (2014:38) sinematografık hareket-imajın özü, araçlardan ya da hareketli cisimlerden, ortak tözleri olan hareketi ya da hareketlerden bunların özü olan hareketliliği çekip çıkarmaktır. "Hareket imajı, imajlar topluluğunda diğer imaj türlerinin kaynağını oluşturan bir imajdır. Temel bir imaj olarak hareket imajı, tüm evreni, kendisi aracılığıyla kavradığımız bir 'sinematografik kavramdır" (Yılmaz, 2015:44).

Deleuze hareket imajın üç çeşidinden bahseder. Bunlar algılanım-imajlar, eylem-imajlar ve duygulanım-imajlardır. Bu türleri de bir örnekle açıklar (2014, 95-97): Eylem-imaj, karakterin eylemi, hareketi ile ilgilidir. Bu imaj türünde karakter bir hareket ve eylem içerisindedir. 
Eylem-imaj da, kamera hareketleri, montaj ile aktarılır. Beckett' $1 n$ filminde karakter ileri atılip bir duvar boyunca yatay olarak kayıp gider, daha sonra, düşey bir ekseni izleyerek duvarın kenarına tutunarak, bir merdivenden çıkmaya uğraşır. "Bir eylemde bulunmaktadır", bu bir eylemin algılanımıdır ya da bir eylem-imajdır. Daha sonra karakter bir odanın içerisine girer ve burada odadaki şeyleri ve hayvanları algılamaya başlar. Bu an algılanım-imajdır. Daha sonra ise yakın plan çekime geçilir ve karakterin o anki duyguları yakın planla görünür kılınır. Bu ise kendi kendinin algılanımıdır, duygulanım-imajdır. "Bu üç tür çeşide, mekânsal olarak belirlenmiş üç tür plan karşılık gelebilir: Uzak plan özellikle bir algılanım-imaj oluştururken, orta plan bir eylem-imaj, yakın plan da bir duygulanım-imaj olacaktır" (Deleuze, 2014:100).

Deleuze Sinema 1- Hareket İmaj kitabında hareket imajın büyük biçimi ve de küçük biçimini de açıklamaktadır. Deleuze'e göre (2014:210) büyük biçim, durum-eylem-durum, durumdan durumu değişikliğe uğratan eyleme gitmektedir. Oysa tam tersine eylemden duruma, yeni bir eyleme doğru giden bir başka biçim daha vardır: Eylem-durum-eylem. Bu sefer, durumun örtüsünü kaldıran, durumun yeni bir eylemi harekete geçirecek olan bir parçasını ya da bir yanını açığa çıkaran, eylemdir. Eylem el yordamıyla ilerler ve durumun örtüsü de karanlıklar içinde ya da muğlaklık içinde kaldırılır. Eylemden eyleme, durum azar azar ortaya çıkar, değişiklik gösterir ve sonunda ya aydınlığa kavuşur ya da gizemini korur. Kapsayan olarak durumdan düello olarak eyleme giden eylem-imajı Deleuze büyük biçim diye adlandırır. Kolaylık açısından, bir eylemden, bir davranıştan ya da bir habitustan, kısmen örtüsü açılmış bir duruma giden eylem-imajı ise küçük biçim diye adlandırmıştır.

\section{Issiz Adam Filmi}

Hareket imajda mutlaka bir değişim gerçekleşir. Bu değişim ise neden sonuç ilişkisi ile mantıksal bir düzlem çerçevesindedir. Issız Adam filminde de gerek karakterler gerekse eylem ve durumlarda değişimler görülür ve bu değişim mantıksal bir neden sonuç ilişkisi içerisinde ilerler. Filmin başlarında Alper'in nasıl biri olduğu üzerinde durulur. Ve izleyici Alper'i tanımaya başlar, Alper' in mücadele ettiği durumla tanışır. Deleuze'e göre de filmlerin başlangıcı kişilerin tanıtımı ve de problemle karşılaşılması ile ilerler. Daha sonra ana karakter bu problemi çözmek üzere eylemde bulunur. Sonrasında ise mutlu son ya da mutsuz bir son oluşmaktadır. Film bu şekilde Deleuze'un bahsettiği büyük biçim ile durum-eylem-durum şeklinde ilerlemektedir. Issız Adam filminin ilk sahnesinde Alper sosyal medyada Şeyma nickli bir kadınla cinsel içerikli konuşmaktadır. Sonrasında sosyal medyada yazıştığı kadın olduğu anlaşılan kişinin evine gider, kadın onu yatak odasına yönlendirir. Filmin başında gösterilen bu görüntülerle ve filmin ilerleyen bölümlerinde buna benzer görüntülerin tekrar edilmesi ile Alper'in yaşantısı hakkında izleyiciye bilgi sunulmaktadır: Alper, tek başına yaşayan, arkadaşı olmayan ve günübirlik ilişkilerle cinsel arzularını tatmin eden bir adam olarak karşımıza çıkar. Bu, filmde Alper'in farklı zamanlarda sık sık cinsellik yaşaması ve etrafında kimsenin olmaması ile görünür kılınmaktadır. Alper'in filmde bu şekilde sunulması ile izleyicide her şeyi çabuk tüketen ve hayatı anlık yaşayan biri olduğu algısı oluşmaktadır. Fakat Alper'in bu durumu Ada'ya aşık olması ile değişim gösterir. Her şeyi çabuk tüketen ve bulunduğu toplumun normlarına karşı çıkan Alper filmin sonlarına doğru aile babası gibi davranmaya başlar. Ahlaki açıdan bu değişim karakterin kendi arzularından sıyrılması ve de aşkın kendi arzusundan daha üstün olduğu mesajını da görünür kılmaktadır.

“Hareket-imgesinin en belirgin biçimi olan eylem-imajı, doğrudan ana karakterin anlatı mekanı içindeki amaçlı eylemliliği etrafında örgütlenmiştir. Böylece anlatı, temel çatışmalar 
içeren durumların ortaya konması ve daha sonra bu çatışmaların anlatı mantığı içerisinde ana karakter aracılığıyla çözümlenmesi biçiminde ilerler" (Suner, 2006:121).. Filmde Alper'in doğup büyüdüğü yerin toplumsal yapısı ve kendi özgür iradesi ile yaşama arzusu arasında bir çatışma görülür. Alper'in ailesi filmde kırsal kesim insanını akla getirmektedir. Bu ayrım, Alper'in annesi ile yaptığı telefon konuşmasında görülmektedir. Bu sahnede Alper modern bir evde yalnız başına cep telefonu ile konuşurken annesi geniş bir aile ile eski tüplü bir televizyonun yanında, eski ev telefonu ile konuşmaktadır. Filmde bu şekilde ana karakterin çatışma durumu tanıtılmaktadır.

Hareket imajda karakter bir soruna karşı tepki verme eğilimindedir. Böylelikle hareket imaj sinemasında izleyici karakterle özdeşleşir. Çünkü hareket imajda karakter izleyici durumunda değil, eylemde bulunma durumundadır. Issız Adam filminde Alper'in özgür iradesi ile Ada' dan ayrılması, yaşadığı toplum normlarının koyduğu evlilik müessesine karşı koyuşudur. Bu ayrılık sahnesi öznel kamera ile Alper'i izleyici konumunda verdiğinden, izleyici Alper ile özdeşleşmeyi tam sağlayamamaktadır. Fakat bu sahnede Ada'nın tepkisi yakın planla verilmektedir. Bu Deleuze'un bahsettiği duygulanım imaj anıdır ve izleyici Ada ile özdeşleşme yaşar. Hume'a göre (2009:219) duygular daha doğal olarak imgelemden ve onlara ilişkin olarak oluşturduğumuz her diri tasarımdan doğarlar. Duygudaşlığın doğası ve nedeni budur; başkalarının görüş ve duygularını saptadığımız zaman onlara bu yolla derinlemesine gireriz. Bu, yakın plan çekimlerle de sağlanmaktadır. Aslında filmde iyi ya da kötü diyebileceğimiz bir karakter yoktur. Fakat karakterler soruna tepki verdiklerinden ve de eylemde bulunduklarından izleyici bu iki karaktere ve de onların duygularına yakınlık duymaktadir.

\section{Dedemin İnsanları Filmi}

Filmde, Mehmet Bey'in görüldüğü ilk sekansta Mehmet Bey beyaz takım elbise; siyah, parlak, temiz bir çift ayakkabı ve siyah çorap giyinmiştir ve beyaz bir arabadan inerek kavga eden çocuklara doğru ilerler. Görüntü aşağıdan yukarıya doğrudur ve kamera hareketi devam ettikçe beyaz şapkalı, gri kravatlı, beyaz yelekli ve beyaz ceketli Mehmet Bey görülür. Hume'a göre (2009:290) imgelem alçaktan yükseğe geçerken içsel nitelik ve ilkelerinde bir karşıtlık bulur. İmgelemin bu can atan ilerleyişi zihnin şimdiki durumuna uyar ve güçlük, onun dinçlik ve şevkini söndürmek yerine, onu sürdürme ve artırma biçimindeki karşıt sonucu doğurur. Erdem, deha, güç ve zenginlikler bu nedenle yükseklik ve yücelik ile ilişkilendirilirler; tıpkı yoksulluk, kölelik ve budalalığın iniş ve aşağılık ile ilişkilendirilmesi gibi. Mehmet Bey'in de bu giyim tarzı onun özenli, temiz biri olduğu; alt çekimin kullanılması erdemli, yüksek mevkide -ki Mehmet Bey yaşadığı çevrede saygı gören, ahlaki yönden üstün bir karakterdirbiri olduğu algısı yaratır. Ayrıca canlı ve sıcak renkler de duygusal olarak mutlu ve neşeli bir durum algısı oluşturmaktadır.

Filmin ana karakterini oluşturan Mehmet Bey de filmin başından sonuna kadar aktif konumdadır. Yaşadığ1 yerde ötekileştirme sorunu vardır. Mehmet Bey ise ötekileştirmeye karşıt bir tavırla davranmaktadır. Hareket imaj açısından bakıldığında Mehmet Bey bir çatışma içerisindedir: Ötekileştirme sorunu ile karşı karşıyadır ve bu sorunla mücadele etmek üzere eyleme geçme gerekliliğinin izleyici de farkındadır. Filmin sonunda ise eylemden tekrar başka bir duruma geçildiği görülür. Bu filmde de anlatı iki karakter üzerinden ve iki parçada gerçekleşmektedir ve durum-eylem-durum şeklinde Deleuze'ün hareket imajın büyük biçimi olarak adlandırdığı şekilde ilerlemektedir. Merkez nokta ise anlatı ilerledikçe 
değişiklik gösterir. İlk başta Mehmet Bey üzerinden ilerleyen anlatı filmin sonlarına doğru Ozan üzerinden ilerlemeye başlamıştır. Böylelikle iki karakterin hayatı ve çatışması filmde görünür kilınmaktadır.

Hareket imajın bir diğer özelliği de önemli ile önemsiz olan şeylerin ayırt edilebilecek şekilde olmasıdır. Çünkü hareket imajda eylemler merkezdedir. Dedemin İnsanları filminde de neyin önemli neyin önemsiz olduğu ya da neyin ahlaki neyin ahlaki olmadığı kolayca ayırt edilebilmektedir. Mehmet Bey'in hayatını sonlandırması eylemi de bunu ayırt edebilmeyi sağlamaktadır. Toplumun içerisinde bulunduğu durumun Mehmet Bey'in doğduğu yere kavuşma arzusundan daha önemli olduğu bu intihar eylemi ile karşımıza çıkar. Ayrıca filmde Türklük - gavurluk çatışması ile biz bilincinin vurgulanması da aslında birlik ve beraberliğin ve de ailenin önemini anlaşılır kılmaktadır.

\section{Unutursam Fisılda Filmi}

Unutursam Fısılda filminde Hanife ve Hatice ismindeki iki kardeşin birbiriyle çatışması konu edilmektedir. Bu kardeşler birbirinden farklı karakteristik özelliklere sahip karakterlerdir. $\mathrm{Bu}$ filmde de karakterlerin eylemi gerçekleştirme nedenleri verildiğinden izleyici karakterler hakkında iyi ya da kötü diye bir ayrımda bulunamamaktadır.

Filmde Hatice, ablası Hanife' nin şiir defterini çalar ve hayallerini gerçekleştirmek için Tarık ile İstanbul'a kaçar. Böylelikle bir eylemde bulunarak mücadele ettiği durumu çözüme kavuşturmaya çalışır. Hatice bu eylemi sonucu kendi arzularını gerçekleştirmiştir, bu eyleminin sonucunda da mutlu olmuştur. Fakat hırsızlık yaparak ahlaki bir eylemde bulunmamıştır ki filmde bu eylemi, her ne kadar nedeni arzularına ulaşmak da olsa, ahlaki olarak gösterilmez. Çünkü Hatice, ablasının defterini çalarak kazandıklarını, filmin sonunda kaybetmiştir. Bu filmde de kişilerin özgür iradeleri ile kendi arzularını gerçekleştirmelerinin ahlaki bir davranış olarak görüldüğü fakat bu eylemler sonucunda başkalarına zarar vermenin ahlaki olmadığı algısının yaratıldığı görülmektedir. Hanife'nin mutsuz olma nedeni özgür iradesi ile hareket etmemesidir. Dolayısıyla Hanife açısından eylemsizlik söz konusudur. Hanife, toplumun kendisine biçmiş olduğu rolü oynar ve bu nedenle de mutsuz bir hayat geçirir. Bu filmde de merkezde ilk olarak Hatice yer alırken filmin sonlarına doğru Hanife filmin merkezine geçer. İlk başta olaylara yön veren Hatice filmin sonunda negatif özne konumuna geçmektedir. Filmin başında negatif özne konumunda olan Hanife ise filmin sonunda olaylara yön veren, aktif bir karakter olarak karşımıza çıkar. Böylelikle anlatı iki karakter üzerinden ve karakterlerin eylemleriyle ilerlemektedir.

Bu filmde de durum- eylem -durum şeklinde hareket imaj görülmektedir. Filmde ilk olarak Hatice ve Hanife tanitılır. Hatice' nin içerisinde bulunduğu durum ile arzularının çatışması bir sorun olarak göze çarpar. Hatice bu durumla mücadele etmek üzere eyleme geçer ve bu eylemi sonucunda başarılı olur. Fakat sonrasında anlatı yön değiştirir ve filmin başında negatif konumlanmış özne durumundaki karakter olan Hanife'nin eyleme geçtiği görülür. $\mathrm{O}$ da sorun karşısında eyleme geçmiştir. Böylelikle kişilerin tutku ve arzularının ötesinde kardeşlik, aile ve aşkın çok daha önemli olduğu düşüncesi oluşmaktadır.

\section{Sonuç}

ÇağanIrmakhemmelodramhem detragedyanınanlatıunsurlarındanyararlanmaktadır. 
Bununla birlikte bu her iki türün ahlak dersi verme ve ahlaki değerleri vurgulama işlevlerinden de yararlanmaktadır. Fakat Çağan Irmak filmlerinde, bu unsurlar ve de ahlak anlayışı, bu türlerdeki kullanımından farklılaşmaktadır.

Irmak filmlerinde karakterler arzularını gerçekleştirmek için mücadele ederler. Eyleme geçerler. Nitekim arzularına kavuşurlar fakat arzularına kavuşmalarının sonrasında başka sorunlarla karşılaşırlar. Ahlaki açıdan değerlendirildiğinde kişilerin arzularını gerçekleştirmeleri kişiyi mutluluğa ulaştırdığından ahlaki kabul edilebilir. Fakat Irmak filmlerinde filmin başlarında kişisel arzular ön planda olduğundan, bu mutluluk karakterlere indirgenmektedir. Kişilerin kendi arzularına ulaşması konusunda mükafatlandırılma ya da cezalandırılma diye bir durum söz konusu değildir. Bu davranış kişinin tamamıyla özgür iradesi ile gerçekleştiğinden ve de kişinin kendi hayatına ilişkin olduğundan gayri ahlaki görülmeyebilir. Fakat karakterlerin hatalı eylemleri vardır ve bu eylemler sonucunda başka insanlar zarar görüyorsa bu durumda karakterler arzuları ile kazandıklarını kaybetmekle cezalandırılmaktadırlar. Melodramın ahlak görüşünde toplumsal düzene ve de toplumdaki baskın anlayışa göre şekillenen muhafazakar bir ahlak anlayışı görülür. Tragedyada ise bilgi ve erdem ile ahlakiliğin açıklandığı bir ahlak anlayışı hakimdir. Çağan Irmak filmlerinde ise karakterler yaşadıkları toplumda kendilerinden beklenen davranışları gerçekleştirmezler. Tam tersi yaşadıkları toplum tarafından kendilerine diretilen davranış modellerini reddederek kendi arzularını gerçekleştirirler. Nitekim bu eylemlerinin sonucunda mutlu olurlar. $\mathrm{Bu}$ şekilde Çağan Irmak filmlerinde, toplumda hakim olarak diretilen ahlaki görüşe karşı bir duruş olduğu söylenebilir. Bu açıdan değerlendirildiğinde Çağan Irmak filmlerindeki ahlaki görüşün toplumla sınırlandırılmayan evrensel ve özgür iradeye dayalı bir ahlak anlayışı olduğu söylenebilir.

Melodramların anlatı yapısında olduğu gibi Çağan Irmak filmlerinde de çatışma ve karşıtlıklardan yararlanılmaktadır. Fakat bu karşıtlıklar melodramlardaki gibi karakterlerin ahlaki durumlarını yansıtmak amacıyla değil, karakterler arasındaki çatışmayı ortaya çıkarmak amacıyladır. Melodramlarda karakterler üzerinden yansıtılmaya çalışılan ahlak anlayışından farklı olarak, Çağan Irmak filmlerinde karakterler ne iyi ne de kötüdürler. Onlar sadece arzularını gerçekleştirmeye çalışırlar ve bu arzularını gerçekleştirme isteklerinin altında yatan nedenler görünür kılınarak izleyicinin onlara yakınlık duyması sağlanmaktadır. İzleyici birbiri ile çatışan her iki karakterin de davranışlarının altında yatan nedeni bildiğinden her iki karakterin davranışına da hak vermektedir. Karakter açısından Çağan Irmak filmleri tragedya anlatılarına daha yakındır. Çünkü bu karakterler gerçeğe daha yakın ve doğuştan iyi kabul edilen karakterlerdir. Fakat tragedyada karakterler arzularına ulaşmazlar. Çünkü mücadele ettikleri durum kendi arzularından çok daha değerlidir. Dolayısıyla tragedyanın sonunda karakter ya yenilir ya da ölür. Çağan Irmak filmlerinde ise karakterler arzularına kavuştukları için mutludurlar. Onları asıl mutsuz eden, arzularına ulaştıklarından sonra başlarına gelen talihsiz olaylar sonucundadır. Bu talihsiz olaylara ise Çağan Irmak filmlerinde, çatışan karakterleri bir araya getirmek, aile ve insanın doğasına yönelik ahlaki değerleri vurgulamak için başvurulmaktadır. Ayrıca tragedya anlatılarında karakter tutarlıdır, yani başında nasılsa anlatının sonunda da aynıdır. Dolayısıyla gerek melodram gerekse tragedyada karakterler daha pasif durumdadırlar. Oysa Çağan Irmak filmlerinde karakterler düşünsel ve de karakteristik özellikler bakımından değişim göstermektedirler. Bu değişim sonucunda kendi arzularından daha önemli değerlerin olduğu bilincine vararak hatalarını görebilmektedirler. Ahlaki açıdan bakıldığında karakterlerin hatalı davranışlarını görerek yaptıklarından bir ders çıkarmaları 
da bu şekilde sağlanmaktadır. Böylelikle izleyici ahlaki açıdan önemli olanın evrensel ahlaki değerler olduğunun algısına da varmaktadır.

Ahlakın temel kavramları arasında özgürlük de yer almaktadır. Ahlaki açıdan kişilerin özgür iradeleri ile karar almaları ve eyleme geçmeleri gerektiği düşünüldügüünde Çağan Irmak filmlerinde özgürlükçü bir ahlak anlayışı olduğu söylenebilir. Melodramlarda karakterler negatif konumlanmış özne konumundadırlar. Dolayısıyla başlarına gelen olaylara karşı pasif bir durum sergilerler ve ilahi bir gücün iyi karakteri mükafatlandırması söz konusudur. Tragedyada da karakterin baht dönüşümü gerçekleşir. Bu durum ya karakterin bilgisizlikten yaptığı bir hata ile ya da kaderin yönlendirmesi ile gerçekleşir. Her iki türde de karakterler yaptıkları davranışların sorumluluğunu üstlenir, iyi davranışlarından dolayı mükafatlandırılıp kötü davranışlarından dolayı cezalandırılırlar. Çağan Irmak filmlerinde de karakterler yaptıkları davranışların sorumluluğunu üstlenmekle birlikte, kendilerinden beklenen davranışları gerçekleştirmeyip kendi özgür iradeleri ile hareket ederek, özgürlükçü bir tavır sergilemektedirler. Dolayısıyla bu filmlerde karakterler eylemlerinden kendileri sorumludurlar. Nitekim bu nedenle de başkalarını suçlamaz ve eylemlerinden dolayı pişmanlık da duymazlar. Karşı oldukları şey, özgür iradeleri ile eylemlerini gerçekleştirememeleridir.

Irmak filmleri ikili bir anlatı yapısına sahiptir. Bu filmlerde birbiriyle çatışan her iki karakterindegerçekleştirmekistediğiarzularıvardır. Nitekimbuarzularına dakavuşurlar. Fakat bu arzulara kavuşmak için yaptıkları eylemler yaşadıkları toplumda ahlaki görülmemektedir. Daha sonraki anlatıda ise ana karakter, başına gelen talihsiz olaylar sonucu çatıştığı karakter ya da durumla bir araya gelir. Bu bir araya gelme durumu karakterlerin hatalarını görmelerine ve de kendi arzularından çok daha değerli ahlaki bir görüşe yönelmelerine neden olur. Kısaca izleyici hem karakterin arzusuna yönelmesine hak verir hem de filmin sonunda karakterlerin tutku ve arzularından arınması ile evrensel bir ahlak anlayışının vurgulandığına şahit olur.

\section{Kaynaklar}

Akarsu, Bedia (1998). Mutluluk Ahlakı. İstanbul: İnkılap Kitabevi.

Akbulut, Hasan (2008). Kadına Melodram Yakışır: Türk Melodram Sinemasında Kadın İmgeleri. İstanbul: Bağlam Yayınları.

Aktan, Coşkun Can (2009). "Ahlak ve Ahlak Felsefesine Giriş". Hukuk ve İktisat Araştırmaları Dergisi. 1(1), s. 38-59.

Aristoteles (1987). Poetika, İsmail Tunalı (çev.), İstanbul: Remzi Kitabevi.

Aristoteles (2014). Nikomakhos'a Etik, Furkan Akderin (çev.), İstanbul: Say Yayınları.

Barut, Basri (2001). "Türk Basınında Etik”. 1. Ulusal Uygulamalı Etik Kongresi Kitabı. Ankara: Ortadoğu Teknik Üniversitesi Felsefe Bölümü, s. 142-147.

Billington, Ray (1997). Felsefeyi Yaşamak: Ahlak Düşüncesine Giriş, Abdullah Yılmaz (çev.), İstanbul: Ayrıntı Yayınları.

Birand, Kamıran (1958). İlk Çağ Felsefesi Tarihi. Ankara: Ajans Türk Matbaası.

Brooks, Peter (1995). The Melodramatic Imagination: Balzac, Henry James, Melodrama and The Mode of Excess, New Haven. CN: Yale University Press.

Cevizci, Ahmet (2001). Ortaçağ Felsefesi Tarihi. Bursa: Asa Kitabevi. 
Cevizci, Ahmet (2001a). Onyedinci Yüzyıl Felsefesi Tarihi. Bursa: Asa Kitabevi.

Çelebi, Nilgün (2003). “Ahlak, Etik ve Toplum”. Bilge: Yayın Tanıtım Eleştirel Tahlil Dergisi. (39), s. 3-11.

Çüçen, Kadir (1999). Felsefeye Giriş. Bursa: Asa Kitabevi.

Dedeoğlu, Gözde (2004). Etik Düşünce ve Postmodernizm. İstanbul: Telos Yayıncılık. Yayıncilik.

Deleuze, Gilles (2014). Hareket İmge, Soner Özdenir (çev.), İstanbul: Norgunk

Descartes, Rene (1942). Metafizik Düşünceler, Mehmet Karasan (çev.), İstanbul: Maarif Matbaas1.

Fromm, Erich. (2005). Kendini Savunan İnsan: Ahlak Psikolojisi Üzerine Bir Araştırma, Devrim Doğan Yüzer (çev.), İzmir: İlya Yayınları.

Gökalp, Nurten (2010). Duygu ve Etik. Ankara: Ebabil Yayınları.

Gündüz, Mustafa (2010). Ahlak Sosyolojisi. Ankara: Anı Yayıncılık.

Hobbes, Thomas (2007). Leviathan: Veya Bir Din ve Dünya Devletinin İçeriği, Biçimi ve Kudreti, Semih Lim (çev.), İstanbul: Yapı Kredi Yayınları.

Hume, David (2009). İnsan Doğası Üzerine Bir İnceleme, Ergün Baylan (çev.), Ankara: Bilgesu Yayınları.

Kant, Immanuel (2002). Ahlak Metafiziğinin Temellendirilmesi, İoanna Kuçuradi (çev.), Ankara: Türkiye Felsefe Kurumu Yayınları.

Nietzche, Friedrich (2001). İyinin ve Kötünün Ötesinde: Bir Gelecek Felsefesini Açış, Ahmet İnam (çev), İstanbul: Yorum Yayınevi.

Nutku, Özdemir (1990). Dram Sanatı. İstanbul: Kabalcı Yayınları.

Özsoy, Aydan (2004). “Türkiye'de 1960’lar Dönemi Aile Melodramlarında Kadın ve Erkek İmgesi". Sinemada Anlatı ve Türler, Ahmet Gürata, Fatma Küçükkurt (Ed.), Ankara: Vadi Yayınları, s. 277-300.

Platon (1998). Sokrates'in Savunması, Niyazi Berkes (çev.), İstanbul: Cumhuriyet Yayınları.

Platon (1999). Mektuplar, İrfan Şahinbaş (çev.), İstanbul: Çağdaş Matbaa ve Yayıncılık.

Platon (2012). Devlet, Cenk Saraçoğlu ve Veysel Atayman (çev.), İstanbul: Bordo Siyah Yayınları.

Platon (2013). Menon, Furkan Akderin (çev.), İstanbul: Say Yayınları.

Rousseau, Jean Jacques (1987). Toplum Sözleşmesi, Vedat Günyol (çev.), İstanbul: Anadolu Yayıncilık.

Spinoza (2011). Etika, Hilmi Ziya Ülken (çev.), Ankara: Dost Kitabevi Yayınları.

Suner, Asuman (2006). Hayalet Ev: Yeni Türk Sinemasında Kimlik, Aidiyet ve Bellek. İstanbul: Metis Yayınları. 
Sütçü, Özcan Yılmaz (2015). Gilles Deleuze'de İmge Hareketi Olarak Sinemanın Felsefesi. İstanbul: Sentez Yayınc1lık.

Şener, Sevda (2006). Dünden Bugüne Tiyatro Düşüncesi. Ankara: Dost Kitabevi Yayınları.

Topçu, Nurettin (2014). Ahlak. İstanbul: Dergah Yayınları.

Uslu, Mehmet Fatih (2011). Melodram Ve Komedi: Osmanlı'da Türkçe ve Ermenice Modern Dramatik Edebiyatlar. Yayınlanmamış Doktora Tezi, İhsan Doğramacı Bilkent Üniversitesi, Ankara. 


\title{
Toros Yayla Köylerinde Sinema Deneyimleri: Modernlik, Şehir, Sinema Ve Seyirci İlişkilerine Dair Bir Soruşturma ${ }^{1}$
}

\author{
Aydin Çam* \\ İlke Şanlıer**
}

\section{Özet}

$\mathrm{Bu}$ çalışma, anaakım sinema tarihi araştırmalarının geleneksel yöntemlerinden belirgin biçimde ayrllarak, Yeni Sinema Tarihi yaklaşımından hareketle 1960-1980 yılları arasında, Adana'ya 170, Mersin'e 70 kilometre mesafede ve yaklaşık 1.500 metre rakımda konumlanan Toros yayla köylerindeki sinema deneyimlerini merkezine almaktadır. Temel amaç, bahsi geçen dönemde salonlarda ya da seyyar sinemalar aracılığıyla Toros yayla köylerinde gerçekleşen seyir deneyimlerini araştırmak; eğer yaşandıysa, sinemayla birlikte gerçekleşen kültürel değişimleri/dönüşümleri saptamak ve çözümlemektir. Bu bağlamda bazı araştırma soruları şöyle sıralanabilir: (1) 1960-1980 yılları arasında Toros yayla köylerinde film gösterimleri hangi mekânlarda, hangi koşullarda ve hangi etkinliklerle gerçekleştirilmiştir? (2) Gerçekleştirilen gösterimlere kimler katılmıştır ve bu katılımcıların seyir deneyimleri nelerdir? (3) Bahsi geçen dönemde, yayla köylerindeki seyir deneyiminin gündelik hayattaki yansımalarn nelerdir? (4) Sinemayla birlikte, bahsi geçen köylerde bir kültürel dönüşüm yaşanmış mıdır? Ĕ̆er yaşandıysa bu dönüşümü nasıl tanımlayabiliriz? Araştırmayı gerçekleştirmek için yazar ve senarist Osman Şahin'in çalışmalarından hareketle seyyar sinemacılarn film gösterimi yaptıkları izlekler çıkarılarak yayla köyleri belirlenmiştir. Araştırmanın gerçekleştirileceği köylerin belirlenmesinde Osman Şahin'in 1974'te Yedinci Sanat dergisi için gerçekleştirdiğ “ “Toros Dağları'nda Sinema Soruşturması" adlı söyleşide konuştuğu seyyar sinemacı Musa Özder'in ifadelerinden yararlanılmıştır. Buradan hareketle araştırma, Mersin ili sınırları içinde bulunan Toros yayla köylerinde 1960-1980 yılları arasında yapılan seyyar sinema gösterimlerini izlemiş, 1970 yılı ve öncesinde doğan katılımcılarla sözlü tarih yöntemiyle gerçekleştirilmiştir. Araştırma sonucunda bahsi geçen köylerdeki sinema etkinliklerinin, seyir mekânlarının ve deneyimlerinin, Batıl geleneksel/konvansiyonel sinema çalışmalarının önermelerinden son derece farklı biçimlerde gerçekleştirildiği görülmüştür ve çalışmada bu farklilıklar değerlendirilmektedir.

Anahtar Kelimeler: Çukurova Bölgesi Sinema Tarihi, Yeni Sinema Tarihi, Seyirci Deneyimleri, Köy Sinemaları, Seyyar Sinema

ORCID ID : 0000-0002-4168-3093 \& 0000-0002-0971-3379

E-mail : aydinaksu@gmail.com; ilkesanlier@gmail.com

DOI: $10.31122 /$ sinefilozofi.514088

Geliş Tarihi - Recieved: 17.01.2019

Kabul Tarihi - Accepted: 15.04.2019

1 Bu çalışma Çukurova Üniversitesi Bilimsel Araştırma Projeleri Koordinasyon Birimi tarafından desteklenen SBA-2018-10631 kodlu ve Sinema Çerçileri - Toros Dağlarında Seyyar Sinema Deneyimi başlıklı bireysel araştırma projesi kapsamında gerçekleştirilmiştir. Çalışmanın ilk hali 23-25 Kasım 2018 tarihleri arasında Akbank Sanat Beyoğlu / Ístanbul'da gerçekleştirilen 1. Ulusal Sinema ve Felsefe Sempozyumu'nda Sinema Çerçileri - Toros Dağlarında Sinema Deneyimi başlığıyla sözlü bildiri olarak sunulmuştur. 